\title{
Questes
}

\section{Travaux d'aiguille et tissage du texte. Étude des héritières de Merlin dans les romans arthuriens en prose}

\section{Laurence Élisa Cousteix}

\section{OpenEdition}

\section{Journals}

Édition électronique

URL : http://journals.openedition.org/questes/3403

DOI : $10.4000 /$ questes.3403

ISSN : 2109-9472

Éditeur

Les Amis de Questes

Édition imprimée

Date de publication : 15 septembre 2008

Pagination : 41-51

ISSN : 2102-7188

\section{Référence électronique}

Laurence Élisa Cousteix, «Travaux d'aiguille et tissage du texte. Étude des héritières de Merlin dans les romans arthuriens en prose », Questes [En ligne], 15 | 2008, mis en ligne le 01 janvier 2014, consulté le 28 avril 2019. URL : http://journals.openedition.org/questes/3403 ; DOI : 10.4000/ questes.3403

Ce document a été généré automatiquement le 28 avril 2019.

(c) Association des amis de «Questes » 


\section{Travaux d'aiguille et tissage du texte. Étude des héritières de Merlin dans les romans arthuriens en prose} Laurence Élisa Cousteix

NOTE DE L'ÉDITEUR

Cet article n'a pas encore fait l'objet d'une autorisation de publication.

INDEX

Mots-clés : quotidien, Merlin, tissage, prophétie, Parque, Arthur, Morgane, Dame du Lac Keywords : everyday life, Merlin, weaving, prophecy, Parcae, Morgan Le Faye, Lady of the Lake, Arthur 